Article

\title{
Components of Volatile Fractions from Eucalyptus camaldulensis Leaves from Iraqi-Kurdistan and Their Potent Spasmolytic Effects
}

\author{
Dlzar A. Kheder 1,2,*(D), Omar A. M. Al-Habib ${ }^{1,3}$, Gianluca Gilardoni ${ }^{2,4, *(\mathbb{D})}$ and \\ Giovanni Vidari $2,5, *$ \\ 1 Biology Department, Faculty of Science, University of Zakho, Duhok 42001, Kurdistan Region, Iraq; \\ habbibomar@yahoo.com \\ 2 Department of Chemistry, University of Pavia, Via Taramelli 10, 27100 Pavia, Italy \\ 3 Department of Biology, College of Science, International University of Erbil, Erbil 44001, \\ Kurdistan Region, Iraq \\ 4 Departamento de Química y Ciencias Exactas, Universidad Técnica Particular de Loja, San Cayetano Alto \\ s/n, Loja 1101608, Ecuador \\ 5 Medical Analysis Department, Faculty of Science, Tishk International University, Erbil 44001, \\ Kurdistan Region, Iraq \\ * Correspondence: dlzar.kheder@uoz.edu.krd (D.A.K.); gianluca.gilardoni@gmail.com (G.G.); \\ vidari@unipv.it (G.V.)
}

Academic Editor: Michiho Ito

Received: 30 December 2019; Accepted: 6 February 2020; Published: 13 February 2020

\begin{abstract}
Inhalation of vapors from a hot tea of Eucalyptus camaldulensis Dehnh. leaves is considered by Iraqi-Kurdistan people an effective spasmolytic and antipyretic remedy for the treatment of respiratory diseases. The constituents of volatile fractions isolated by hydrodistillation from dried leaves of the plant collected in Kurdistan were determined by GC-FID and GC-MS analyses. More than $90 \%$ components were identified. The most abundant constituents were 1,8-cineole, $p$-cymene, $\alpha$-pinene, terpinen-4-ol, aromadendrene, and $\alpha$-terpineol. The different volatile fractions induced relaxation on rat isolated aortic and tracheal rings in concentration-dependent manner. These effects appeared to be due to a complex interaction between various terpenoid components rather than being only due to the main oil constituent, 1,8-cineole. The KCa channel and the NO pathway were not significantly involved in the relaxation mechanism, while $\mathrm{Ca}^{2+}$ channels played a major role in the spasmolytic effects.
\end{abstract}

Keywords: Eucalyptus camaldulensis; Myrtaceae; volatile fractions; Kurdistan traditional medicine; relaxant effects on rat contracted aorta and tracheal rings; calcium channels

\section{Introduction}

The Kurdistan region of Iraq has a rich biodiversity and many medicinal herbs, including Eucalyptus species, are used by local people in traditional medicine since time immemorial [1]. A common antispasmodic and antipyretic remedy for treating respiratory tract diseases is prepared with the leaves of Eucalyptus camaldulensis Dehnh. (family Myrtaceae), also known as river red gum or Murrey red gum tree [2]. A hot tea is made and then the vapors from the aromatic infusion are inhaled by sick people. The empirical knowledge of this traditional medicine is passed on by oral tradition. No scientific rationale has been reported so far and the mechanism of action remains largely uninvestigated.

The leaf essential oils isolated from E. camaldulensis collected in such different countries as Egypt [3], Iran [4-6], Kenya [7], Montenegro [8,9], Pakistan [10,11], and Senegal [12], to cite only some of the most 
recent studies, have been investigated. Moreover, the leaf oil of E. camaldulensis has been reported to have potent antiseptic, antimicrobial properties $[9,13,14]$, and it is commonly used in several countries for treating cough and cold, sore throat and other respiratory diseases [15]. Indeed, compounds with spasmolytic activity have been isolated from an EtOH extract of E. camaldulensis var. obtusa leaves [16]; however, the vasorelaxant effects of volatile fractions has been confirmed so far only by sporadic tests in vitro [17].

Moreover, previous studies point out that there is a considerable variation in the yields and chemical compositions of the volatile fractions isolated from different samples of E. camaldulensis.

For these reasons, it was worthy to study the components of volatile fractions isolated from E. camaldulensis leaves collected in Iraqi-Kurdistan using various isolation techniques. Furthermore, the physiological effects of volatile fractions on respiratory physiology were investigated in detail with the aim of sustaining the traditional use of this antispasmodic remedy with scientific evidence. To this purpose, the relaxant effects of different volatile fractions on the contractility of isolated rat aortic and tracheal rings have been determined. Moreover, in order to shed light on the mechanism of action, the involvement of the $\mathrm{Ca}^{2+}$ and $\mathrm{K}^{+}$channels, and the nitric oxide (NO) pathway in the biochemical processes underpinning the spasmolytic activity of the plant, was tested in vitro.

\section{Results and Discussion}

Powdered air-dried leaves of E. camaldulensis were hydrodistilled in a standard Clevenger-type apparatus, by two different procedures, A and B, which are described in detail in Section 3.4. An oily volatile fraction, named $\mathrm{EO}_{\mathrm{S}}$ was obtained by procedure $\mathrm{A}$, named hydrodistillation with circulating-water. Three oils, named $\mathrm{EO}_{\mathrm{W}}, \mathrm{EO}_{\mathrm{A}}$, and $\mathrm{EO}_{\mathrm{Ar}}$ were obtained by procedure $\mathrm{B}$, named hydrodistillation with non-circulating water. Another crop of dried leaves was submitted to $\mathrm{CO}_{2}$ extraction at atmospheric pressure (see Section 3.5), which afforded an oily residue, named $\mathrm{EO}_{\mathrm{D}}$. All the five oils had a pale yellowish color. They remained liquid even on storage at $-20{ }^{\circ} \mathrm{C}$ in sealed vials and emanated a sharp and very distinct minty/pine smell. Each sample was dissolved in dichloromethane and analyzed by GC-FID and GC-MS.

\subsection{Characteristics of the Volatile Fractions $E O_{S}$ and $E O_{W}$}

The densities of EOs and $\mathrm{EO}_{\mathrm{W}}$ at $22{ }^{\circ} \mathrm{C}$ were 0.95 and $0.93 \mathrm{~g} / \mathrm{mL}$, respectively. They were practically insoluble at $22{ }^{\circ} \mathrm{C}$ in $\mathrm{H}_{2} \mathrm{O}$ and highly soluble in $\mathrm{EtOH}$, dichloromethane and dimethyl sulfoxide (DMSO). Therefore, oil stock solutions for biological tests were prepared in DMSO.

\subsection{Chemical Analysis of Volatile Fractions (EO)}

The chemical compositions of the five different oily volatile fractions (EO) obtained by hydrodistillation (procedures $\mathrm{A}$ and $\mathrm{B}$ ) and by $\mathrm{CO}_{2}$ extraction, are reported in Table 1 , together with the corresponding component percentages from GC-FID chromatograms and calculated linear retention indices (LRI). 31 components were identified in the volatile mixture $\mathrm{EO}_{\mathrm{S}}$. Major components (see Figure 1) were 1,8-cineole $(\mathbf{1}, 62.70 \%), p$-cymene $(\mathbf{2}, 6.70 \%), \alpha$-pinene $(3,4.71 \%)$, terpinen-4-ol $(4,3.86 \%)$, aromadendrene $(5,3.08 \%)$, and $\alpha$-terpineol $(6,2.85 \%)$ which together accounted for the $83.9 \% \mathrm{EO}_{\mathrm{S}}$ (Table 1). Forty-two compounds were identified in $\mathrm{EO}_{\mathrm{W}}$, among which 1,8-cineole (59.09\%), $p$-cymene $(6.55 \%)$, aromadendrene $(3.97 \%)$, terpinen-4-ol $(3.9 \%), \alpha$-pinene $(3.75)$, and $\alpha$-terpineol $(2.94 \%)$ were the most abundant ones, accounting for the $80.2 \% \mathrm{EO}_{\mathrm{W}} .35$ compounds were identified in $\mathrm{EO}_{\mathrm{A}}$ and the most abundant ones were 1,8-cineole (53.41\%), terpinen-4-ol (6.96\%), $\alpha$-terpineol $(6.70 \%)$, cryptone $(6.69 \%)$, and spathulenol $(2.57 \%) . \mathrm{EO}_{\mathrm{Ar}}$, contained 40 identified components and it was enriched in $\alpha$-terpineol (17.26\%), cryptone (13.92\%), p-cymen-8-ol (13.48\%), 1,8-cineole (10.14\%), and spathulenol (5.74\%). EO $\mathrm{D}_{\mathrm{D}}$ contained only ten identified components, among which 1,8-cineole $(89.25 \%)$, p-cymene (3.44\%), and spathulenol (2.58\%) were the most abundant ones. 
Table 1. Chemical components and their percentages (\%) in the different volatile fractions (EO) isolated from E. camaldulensis leaves ${ }^{a}$.

\begin{tabular}{|c|c|c|c|c|c|c|c|c|}
\hline Component & $R I^{\mathrm{b}}$ & $L R I^{\mathrm{c}}$ & $\mathrm{EO}_{\mathrm{S}}{ }^{\mathrm{d}}$ & $\mathrm{EO}_{W}{ }^{\mathrm{d}}$ & $\mathrm{EO}_{\mathrm{A}}$ & $\mathrm{EO}_{\mathrm{Ar}}$ & $\mathrm{EO}_{\text {Tot }} \mathrm{e}$ & $\mathrm{EO}_{\mathrm{D}}$ \\
\hline Isovaleric acid $^{f}$ & 848 & 842 & - & - & - & 0.23 & $<0.01$ & - \\
\hline Isopentyl acetate & 869 & 870 & 0.07 & 0.07 & - & - & 0.05 & - \\
\hline Undetermined & & 919 & 0.06 & 0.02 & - & - & 0.01 & - \\
\hline$\alpha$-Pinene $\mathrm{g}(3)$ & 932 & 925 & 4.71 & 3.75 & - & - & 2.73 & 1.89 \\
\hline 4-Methylvaleric acid ${ }^{\mathrm{f}}$ & 949 & 946 & - & - & - & 0.01 & $<0.01$ & - \\
\hline Hexanoic acid ${ }^{f}$ & 990 & 993 & - & - & - & 0.01 & $<0.01$ & - \\
\hline p-Cymene (2) & 1020 & 1024 & 6.70 & 6.55 & 0.16 & - & 4.80 & 3.44 \\
\hline 1,8 -Cineole ${ }^{g}(\mathbf{1})$ & 1026 & 1031 & 62.70 & 59.09 & 53.41 & 10.14 & 55.83 & 89.25 \\
\hline Phenylacetaldehyde ${ }^{\mathrm{f}, \mathrm{g}}$ & 1047 & 1048 & - & - & 0.11 & 0.06 & 0.03 & - \\
\hline p-Mentha-3,8-diene & 1068 & 1065 & 2.44 & 2.28 & - & - & 1.66 & 1.32 \\
\hline$p$-Cymenene & 1089 & 1090 & 0.15 & 0.17 & 0.13 & 0.13 & 0.16 & - \\
\hline Isopentyl isovalerate & 1102 & 1107 & 0.28 & 0.38 & - & - & 0.28 & 0.15 \\
\hline endo-Fenchol & 1114 & 1110 & 0.14 & 0.21 & - & - & 0.15 & - \\
\hline cis- $p$-Menth-2-en-1-ol & 1118 & 1120 & - & - & 0.16 & 0.22 & 0.05 & - \\
\hline$\alpha$-Campholenal & 1122 & 1122 & 0.05 & 0.18 & 0.36 & 0.6 & 0.24 & - \\
\hline trans-Pinocarveol & 1135 & 1138 & 0.94 & 0.95 & - & 3.55 & 0.83 & - \\
\hline trans-p-Menth-2-en-1-ol & 1136 & 1140 & 0.13 & 0.03 & - & 0.16 & 0.03 & - \\
\hline Sabina ketone & 1154 & 1151 & 0.05 & 0.04 & 1.93 & 0.03 & 0.48 & - \\
\hline Pinocarvone & 1160 & 1162 & 0.62 & - & - & - & - & - \\
\hline Umbellulone & 1167 & 1162 & - & 0.31 & 0.23 & 0.01 & 0.28 & - \\
\hline Borneolg & 1165 & 1166 & 0.09 & 0.47 & 1.47 & & 0.68 & - \\
\hline Terpinen-4-ol $\mathrm{g}(4)$ & 1174 & 1177 & 3.86 & 3.90 & 6.96 & 2.70 & 4.56 & 0.39 \\
\hline Cryptone & 1183 & 1184 & 1.34 & 1.10 & 6.69 & 13.92 & 2.90 & - \\
\hline$p$-Cymen-8-ol & 1179 & 1187 & - & - & - & 13.48 & 0.53 & - \\
\hline$\alpha$-Terpineol g (6) & 1186 & 1189 & 2.85 & 2.94 & 6.70 & 17.26 & 4.38 & 0.09 \\
\hline Undetermined & & 1213 & 0.25 & 0.25 & - & 0.01 & 0.18 & - \\
\hline trans-Carveol $\mathrm{g}$ & 1215 & 1219 & 0.14 & 0.15 & 0.65 & 1.02 & 0.30 & - \\
\hline cis-Carveol $\mathrm{g}$ & 1229 & 1222 & - & - & 0.91 & 2.07 & 0.29 & - \\
\hline cis- $p$-Mentha-1(7),8-dien-2- & ol 1227 & 1227 & - & 0.19 & 1.21 & 2.12 & 0.50 & - \\
\hline (E)-Ocimenone & 1235 & 1231 & 0.19 & & 1.73 & 3.81 & 0.55 & - \\
\hline Cuminaldehyde & 1238 & 1238 & 0.11 & 0.12 & 0.32 & 0.39 & 0.18 & - \\
\hline $\begin{array}{l}\text { Carvone }{ }^{g}+ \\
\text { carvotanacetone }\end{array}$ & $1239-1244$ & $1244-1246$ & - & - & 0.32 & 0.55 & 0.10 & - \\
\hline Piperitone $\mathrm{g}$ & $1249^{a}, 1254^{d}$ & 1254 & 0.11 & 0.11 & 0.47 & 0.92 & 0.23 & - \\
\hline$p$-Menth-1-en-7-al & 1273 & 1274 & 0.73 & 0.68 & 1.67 & 3.41 & 1.02 & - \\
\hline$\alpha$-Terpinen-7-al & 1283 & 1283 & - & - & - & 0.01 & $\operatorname{tr}$ & - \\
\hline Thymol g & 1289 & 1289 & 0.49 & 0.58 & 1.78 & 2.52 & 0.93 & - \\
\hline$p$-Cymen-7-ol & 1289 & 1292 & - & - & 0.24 & 0.49 & 0.07 & - \\
\hline Carvacrol g & 1298 & 1302 & 0.39 & 0.44 & 1.15 & 2.73 & 0.69 & - \\
\hline 3-Oxo-p-menth-1-en-7-al & 1330 & 1335 & - & - & 0.35 & 0.39 & 0.10 & - \\
\hline Undetermined & & 1334 & 0.10 & 0.09 & 0.59 & 0.79 & 0.23 & - \\
\hline Undetermined & & 1353 & - & & 0.17 & 0.11 & 0.04 & - \\
\hline Isoledene & 1374 & 1376 & - & 0.09 & - & - & 0.06 & - \\
\hline$\alpha$-Copaene & 1374 & 1378 & - & 0.08 & - & - & 0.07 & - \\
\hline$\beta$-Elemene & 1389 & 1394 & - & 0.03 & - & - & 0.02 & - \\
\hline Undetermined & & 1419 & - & - & 0.13 & 0.06 & 0.03 & - \\
\hline Undetermined & & 1434 & - & - & 0.17 & 0.05 & 0.04 & - \\
\hline$\alpha$-Gurjunene & 1409 & 1412 & - & 0.03 & - & - & 0.02 & - \\
\hline$\beta$-Gurjunene & 1433 & 1432 & - & 0.04 & - & - & 0.03 & - \\
\hline Aromadendrene (5) & 1439 & 1443 & 3.08 & 3.97 & 0.3 & 0.15 & 2.97 & 0.47 \\
\hline 9-epi-(E)-Caryophyllene & 1464 & 1465 & 1.99 & 2.57 & 0.17 & 0.02 & 1.91 & - \\
\hline$\gamma$-Gurjunene & 1475 & 1476 & - & 0.06 & - & - & 0.04 & - \\
\hline$\gamma$-Muurolene & 1478 & 1480 & - & 0.43 & - & - & 0.31 & - \\
\hline $\begin{array}{l}\text { 2-Phenylethyl } \\
\text { 3-methylbutanoate }\end{array}$ & 1490 & 1493 & 0.16 & 0.72 & 0.29 & 0.27 & 0.60 & - \\
\hline Viridiflorene & 1496 & 1499 & - & 0.28 & - & - & 0.20 & - \\
\hline Undetermined & 1520 & 1534 & - & - & 0.10 & 0.22 & 0.03 & - \\
\hline$\alpha$-Muurolene & 1500 & 1504 & - & 0.28 & - & - & 0.20 & 0.42 \\
\hline
\end{tabular}


Table 1. Cont.

\begin{tabular}{|c|c|c|c|c|c|c|c|c|}
\hline Component & $R I^{\mathrm{b}}$ & $L R I^{\mathrm{c}}$ & $\mathrm{EO}_{\mathrm{S}}{ }^{\mathrm{d}}$ & $\mathrm{EO}_{W}{ }^{\mathrm{d}}$ & $\mathrm{EO}_{\mathrm{A}}$ & $\mathrm{EO}_{\mathrm{Ar}}$ & $\mathrm{EO}_{\text {Tot }} \mathrm{e}$ & $\mathrm{EO}_{\mathrm{D}}$ \\
\hline$\gamma$-Cadinene & 1513 & 1518 & - & 0.07 & - & - & 0.05 & - \\
\hline Palustrol & 1567 & 1566 & 0.29 & 0.60 & 0.13 & 0.22 & 0.48 & - \\
\hline Spathulenol & 1577 & 1584 & 1.65 & 1.72 & 2.57 & 5.74 & 2.08 & 2.58 \\
\hline Globulol & 1590 & 1590 & 1.65 & 1.96 & 0.18 & 0.29 & 1.48 & - \\
\hline Viridiflorol & 1592 & 1598 & - & 0.48 & - & - & 0.35 & - \\
\hline $\begin{array}{l}\text { Isoaromadendrene } \\
\text { epoxide } \mathrm{f}\end{array}$ & 1612 & 1610 & 0.37 & - & 0.20 & 0.23 & 0.05 & - \\
\hline Undetermined & & 1630 & 0.21 & 0.45 & 0.13 & 0.19 & 0.36 & - \\
\hline Occidenol & 1676 & 1670 & - & - & 0.32 & 0.57 & 0.10 & - \\
\hline Undetermined & & 1680 & - & - & 0.11 & 0.18 & 0.03 & - \\
\hline Nootkatol & 1714 & 1721 & - & - & 0.02 & 0.01 & $\operatorname{tr}$ & - \\
\hline Undetermined & & 1727 & - & - & 0.74 & 1.64 & 0.24 & - \\
\hline Undetermined & & 1751 & - & - & 0.68 & 1.53 & 0.22 & - \\
\hline $14-O x y-\alpha$-muurolene & 1767 & 1766 & 0.10 & 0.10 & - & - & 0.07 & - \\
\hline Undetermined & & 1774 & - & - & 0.37 & 0.63 & 0.11 & - \\
\hline Undetermined & & 1855 & - & - & 0.05 & 0.12 & 0.02 & - \\
\hline 11,12-Dihydroxyvalencene & 1914 & 1908 & - & - & 0.20 & 0.55 & 0.07 & - \\
\hline $\begin{array}{l}\text { Monoterpene } \\
\text { hydrocarbons (4) } \mathrm{h}\end{array}$ & & & $\begin{array}{c}14.00 \\
(4)\end{array}$ & $\begin{array}{l}12.75 \\
(4)\end{array}$ & $0.29(2)$ & $0.13(1)$ & $9.35(4)$ & $6.65(3)$ \\
\hline $\begin{array}{l}\text { Oxygenated } \\
\text { monoterpenoids (28) } \mathrm{h}\end{array}$ & & & $\begin{array}{l}74.93 \\
(18)\end{array}$ & $\begin{array}{c}71.49 \\
(18)\end{array}$ & $\begin{array}{l}88.71 \\
(22)\end{array}$ & $\begin{array}{c}82.50 \\
(25)\end{array}$ & $\begin{array}{c}75.90 \\
(27)\end{array}$ & $\begin{array}{l}89.73 \\
(3)\end{array}$ \\
\hline $\begin{array}{l}\text { Sesquiterpene } \\
\text { hydrocarbons (12) }\end{array}$ & & & $5.07(2)$ & $\begin{array}{l}7.93 \\
(12)\end{array}$ & $0.47(2)$ & $0.17(2)$ & $\begin{array}{l}5.88 \\
(12)\end{array}$ & $0.89(2)$ \\
\hline $\begin{array}{l}\text { Oxygenated } \\
\text { sesquiterpenoids (9) h }\end{array}$ & & & $4.06(4)$ & $4.86(5)$ & $3.62(7)$ & $7.61(7)$ & $4.68(9)$ & $2.58(1)$ \\
\hline Others $(7) \mathrm{h}$ & & & $0.51(3)$ & $1.17(3)$ & $0.40(2)$ & $0.58(5)$ & $0.96(7)$ & $0.15(1)$ \\
\hline Undetermined (13) $\mathrm{h}$ & & & $0.62(4)$ & $0.81(4)$ & $\begin{array}{l}3.24 \\
(11)\end{array}$ & $\begin{array}{l}5.53 \\
(12)\end{array}$ & $\begin{array}{l}1.54 \\
(13)\end{array}$ & $0.00(0)$ \\
\hline Total $\% \mathrm{~h}$ & & & $\begin{array}{l}98.57 \\
(31)\end{array}$ & $\begin{array}{c}98.20 \\
(42)\end{array}$ & $\begin{array}{c}93.49 \\
(35)\end{array}$ & $\begin{array}{c}90.99 \\
(40)\end{array}$ & $\begin{array}{c}96.77 \\
(59)\end{array}$ & $100(10)$ \\
\hline
\end{tabular}

${ }^{a}$ Only peaks with a $\%>0.01$ have been considered; ${ }^{b}$ Retention Index on a DB- 5 column reported in the literature [18,19]; ${ }^{\mathrm{c}}$ Linear Retention Index on a DB-5 column calculated according to Van del Dool and Kratz [20]; ${ }^{\mathrm{d}}$ mean percentages of three analyses; ${ }^{\mathrm{e}}$ The $\mathrm{EO}_{\mathrm{Tot}}$ value of each compound corresponds to the sum of the percentages in $\mathrm{EO}_{W}, \mathrm{EO}_{\mathrm{A}}$, and $\mathrm{EO}_{\mathrm{Ar}}$, respectively, averaged by the weight of each fraction; ${ }^{\mathrm{f}}$ tentatively identified by comparison with the RI and the mass spectra reported in databases $[19,21]{ }^{g}{ }^{g}$ compound identity confirmed by coelution (GC) with an authentic sample; ' $\mathrm{h}$ Compound families and (total number) of compounds in each family over all EO's.<smiles>CC12CCC(CC1)C(C)(C)O2</smiles>

(1)<smiles>Cc1ccc(C(C)C)cc1</smiles>

(2)<smiles>CC1=CC2CC1C2(C)C</smiles>

(3)<smiles>CC1=CCC(O)(C(C)C)CC1</smiles>

(4)<smiles>C=C1CCC2C(C3C(C)CCC13)C2(C)C</smiles>

(5)<smiles>CC1=CCC(C(C)(C)O)CC1</smiles>

(6)

Figure 1. Structures of main components of leaf essential oil isolated from E. camaldulensis collected in the Iraqi-Kurdistan Region: 1,8-cineole (1), p-cymene (2), $\alpha$-pinene (3), terpinen-4-ol (4), aromadendrene (5), and $\alpha$-terpineol (6).

Considering all the volatile fractions (Table 1), a total of sixty compounds were identified. They comprise 53 terpenoids, among which monoterpenoids (32) exceeded sesquiterpenoids (21) in number and total percentage. Oxygenated monoterpenoids (28) represented by far the most abundant family, followed by monoterpene hydrocarbons, whose number (4) was less than sesquiterpene hydrocarbons (12). 1,8-Cineole (eucalyptol) (1) was the most abundant oil component, followed by $p$-cymene (2), $\alpha$-pinene (3), terpinen-4-ol (4), aromadendrene (5), and $\alpha$-terpineol (6). Comparing the three different 
distillation procedures, hydrodistillation, either in mode $\mathrm{A}$ or $\mathrm{B}$, afforded two oils, $\mathrm{EO}_{\mathrm{S}}$ and $\mathrm{EO}_{\mathrm{W}}$, in comparable yields, and having similar composition, and percentages of most components. In contrast, $\mathrm{CO}_{2}$ extraction was rather inefficient both in terms of oil $\left(\mathrm{EO}_{\mathrm{D}}\right)$ yield and chemical composition. In fact, only the rather non-polar compound 1,8-cineole (1) appeared to be removed from air-dried leaves in an efficient manner. The comparison of $\mathrm{EO}_{\mathrm{A}}$ and $\mathrm{EO}_{\mathrm{Ar}}$ with $\mathrm{EO}_{\mathrm{W}}$ clearly showed that, as expected, the aqueous phase collected in the condenser was enriched in polar oxygenated monoterpenoids and sesquiterpenoids compared to non-polar terpenoid hydrocarbons. Specifically, borneol, terpinen-4-ol (4), cryptone, $\alpha$-terpineol (6), and spathulenol exhibited a significant water solubility. Noticeable amounts of 1,8-cineole (1) were also dispersed in the aqueous phase. Moreover, comparison of $\mathrm{EO}_{\mathrm{Ar}}$ with $\mathrm{EO}_{\mathrm{A}}$ indicated that minor amounts of the most polar terpenoids were not completely removed from the aqueous phase by solid phase extraction (SPE, see Section 3.3).

Our data clearly showed that a significant quantity of oxygenated components remained dispersed in the aqueous phase collected in the condenser during leaf hydrodistillation. Therefore, we considered that a more accurate analysis of E. camaldulensis volatiles should include not only the components of the oil separated from the hydrosol, i.e., $\mathrm{EO}_{W}$, but also the mixture of polar compounds dispersed in the water condensed during the distillation process, i.e., $\mathrm{EO}_{\mathrm{A}}$ and $\mathrm{EO}_{\mathrm{Ar}}$. To this purpose, the column $\mathrm{EO}_{\mathrm{Tot}}$ in Table 1 shows the sum of the percentages of each compound occurring in $\mathrm{EO}_{\mathrm{W}}, \mathrm{EO}_{\mathrm{A}}$, and $\mathrm{EO}_{\mathrm{Ar}}$, averaged by the weight of each fraction. It thus resulted that the percentage of oxygenated monoterpenoids in the total volatile fraction $\mathrm{EO}_{\mathrm{Tot}}$ was significantly higher than in the fraction $\mathrm{EO}_{\mathrm{W}}$ alone, while that of hydrocarbons was lower. Only twelve components of $\mathrm{EO}_{\mathrm{Tot}}$ had an abundance $>1 \%$, namely, 1,8 -cineole $(1,55.83 \%)$, p-cymene $(2,4.80 \%)$, terpinen-4-ol $(4,4.56 \%)$, $\alpha$-terpineol $(6,4.38 \%)$, aromadendrene $(5,2.97 \%)$, cryptone $(2.90 \%), \alpha$-pinene $(3,2.73 \%)$, spathulenol $(2.08 \%)$, 9-epi-(E)-caryophyllene (1.91\%), p-mentha-3,8-diene (1.66\%), globulol (1.48\%), and p-menth-1-en-7-al $(1.02 \%)$, which together accounted for $86.32 \% \mathrm{EO}_{\mathrm{Tot}}$.

Phytochemical results indicate that three chemotypes of E. camaldulensis can be distinguished on the basis of the main components of the oil obtained by hydrodistillation under analogous conditions: one rich in 1,8-cineole (28-84\%), one rich in $p$-cymene (20-30\%) and one rich in spathulenol $(18 \%)[8,22]$. For example, the essential oil from E. camaldulensis leaves collected in Pakistan contained high concentration of oxygenated sesquiterpenes [11], while the main components of the leaf oil hydrodistilled from E. camaldulensis collected in Iran were $p$-cymene (68.43\%), 1,8-cineole (13.92\%), $\alpha$-pinene (3.45\%), and limonene (2.84\%) [4]. Therefore, the compositions of EOs and EO $\mathrm{W}_{\mathrm{W}}$ clearly indicate that the variety of E. camaldulensis growing in Kurdistan can be classified as a chemotype with high 1,8-cineole and low p-cymene contents.

\subsection{Relaxant Effects of E. camaldulensis Volatile Fractions on Aortic Rings}

In a preliminary study we showed that the essential oil of E. camaldulensis produced a potent dilation in aortic force development probably acting as a $\mathrm{Ca}^{2+}$ channel antagonism and partially via NO and cyclooxygenase pathways [17]. To investigate the relationship between oil composition and in vivo spasmolytic effects, the vasorelaxant effects of volatile fractions $\mathrm{EO}_{\mathrm{S}}, \mathrm{EO}_{\mathrm{W}}$, and $\mathrm{EO}_{\mathrm{Ar}}$ on isolated rat aortic rings were determined separately, following the same procedure described previously [17]. The concentration-response curves for the oil-induced relaxation against phenylephrine (PE)-induced contractions are shown in Figure 2, while the percentages of relaxation, the values of $\mathrm{Log}_{50} \mathrm{EC}_{50}$, and $95 \% \mathrm{CI}$ (Confidence Interval) for $\log \mathrm{EC}_{50}$ are shown in Table 2. The curves show that the cumulative addition of the three samples at the plateau of contraction caused a relaxant effect in a concentration-dependent manner, with a strong potent dilation. Relaxation caused by EOW did not differ significantly from $\mathrm{EO}_{\mathrm{S}}$, as it could be anticipated by the comparable chemical compositions of the two oils; instead, significantly minor relaxation effects were observed for $\mathrm{EO}_{\mathrm{Ar}}$. This finding seems to indicate that the reduced relaxant properties of $\mathrm{EO}_{\mathrm{Ar}}$, compared to $\mathrm{EO}_{\mathrm{S}}$ and $\mathrm{EO}$, is caused by the minor amount of 1,8-cineole (1) in $\mathrm{EO}_{\mathrm{Ar}}(10.14 \%)$ than in $\mathrm{EO}_{\mathrm{S}}(62.70 \%)$ and $\mathrm{EO}_{\mathrm{W}}(59.09 \%)$. However, the physiological effects of $\mathrm{EO}_{\mathrm{Ar}}$ were not totally suppressed, due to the significant presence of other 
active terpenoids (Table 1), such as $\alpha$-terpineol $(6,17.26 \%)$ [23], spathulenol (5.74\%) [24], carvacrol $(2.73 \%)$, and thymol (2.52\%) [25].

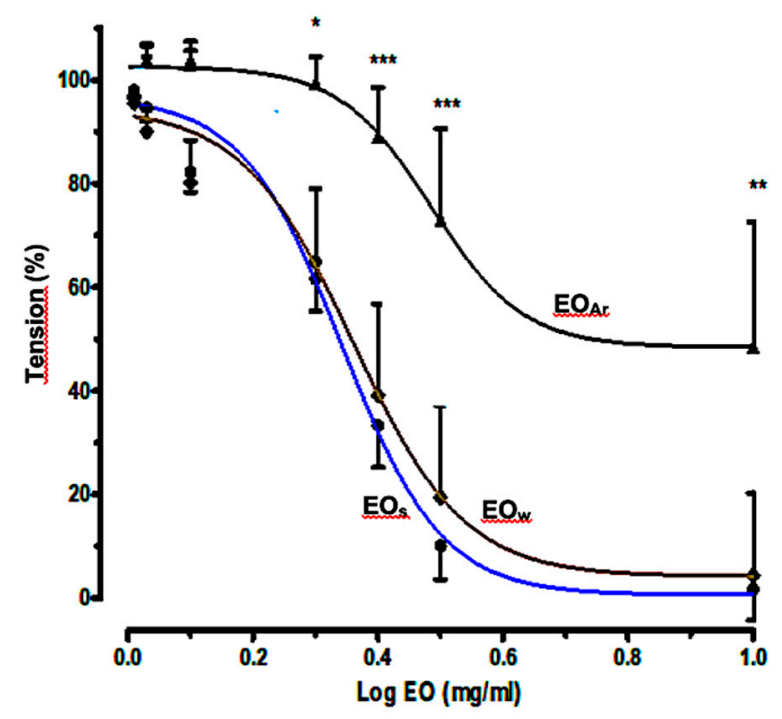

Figure 2. Concentration-response curves for the relaxant effects of volatile fractions $\mathrm{EO}_{\mathrm{S}}, \mathrm{EO}_{\mathrm{W}}$, and $\mathrm{EO}_{\mathrm{Ar}}$ on rat aortic rings precontracted with phenylephrine $(1 \mu \mathrm{M}) .{ }^{*} p<0.05,{ }^{* *} p<0.01$ and ${ }^{* * *} p<0.001$.

Table 2. Relaxant effects of $\mathrm{EO}_{\mathrm{S}}, \mathrm{EO}_{\mathrm{W}}$, and $\mathrm{EO}_{\mathrm{Ar}}$ on rat aortic rings precontracted with phenylephrine $(1 \mu \mathrm{M})$.

\begin{tabular}{cccc}
\hline & EO $_{\mathbf{S}}$ & EO $_{\mathbf{W}}$ & EO $_{\mathrm{Ar}}$ \\
\hline Log EC 50 & 0.3384 & 0.3689 & 0.4852 \\
$95 \%$ CI for Log EC & $0.2974-0.3795$ & $0.2627-0.4571$ & $0.3621-0.6084$ \\
Relaxation (\%) \pm SEM & $95.66 \pm 0.198$ & $88.17 \pm 11.4$ & $72.09 \pm 10.61$ \\
\hline
\end{tabular}

\subsection{Relaxant Effects of $E O_{S}$ and 1,8-Cineole (1) on Rat Tracheal Rings}

Since the oil $\mathrm{EO}_{\mathrm{S}}$ showed the highest activity on rat aortic rings, compared to $\mathrm{EO}_{\mathrm{W}}$ and $\mathrm{EOAr}$, we deemed it to be interesting to measure the relaxant effect of this volatile fraction also in rat tracheal rings. Moreover, the major component of $\mathrm{EO}_{\mathrm{S}}$, namely the monoterpenoid 1,8-cineole (1), was also tested in parallel experiments. In fact, it is well-known that 1,8-cineole (1) displays a wide range of biological effects, including muscle relaxant, bronchodilatatory [26-29], and anti-inflammatory [30,31] properties. Therefore 1,8-cineole (1) was used as the reference compound and its contribution to the biological activity of the volatile fraction $\mathrm{EO}_{\mathrm{S}}$ was roughly estimated. The concentration-response curves for 1,8-cineole (1) and $\mathrm{EO}_{\mathrm{S}}$ relaxant effects against acetyl choline (ACh)-induced contractions are shown in Figure 3. The percentages of relaxation were $33.01 \%$ and $79.44 \%$ for 1,8 -cineole (1) and $\mathrm{EO}_{\mathrm{S}}$, respectively. On the other hand, the $\log \mathrm{EC}_{50}$ were 1.030 and $0.508(\mathrm{mg} / \mathrm{mL})$, respectively. These results clearly indicated that both 1,8-cineole (1) and $\mathrm{EO}_{\mathrm{S}}$ produced potent concentration-dependent relaxation in rat tracheal rings precontracted with $\mathrm{ACh}(10 \mu \mathrm{M})$, although the activity of $\mathrm{EO}_{\mathrm{S}}$ was much higher than that of 1,8-cineole (1) alone. These findings nicely agree with the results of other authors who suggested that the relaxant [26,32] and cardiovascular [33] effects induced by Eucalyptus essential oils appeared to derive from a complex interaction between various terpenoid components rather than being due to a single compound. 


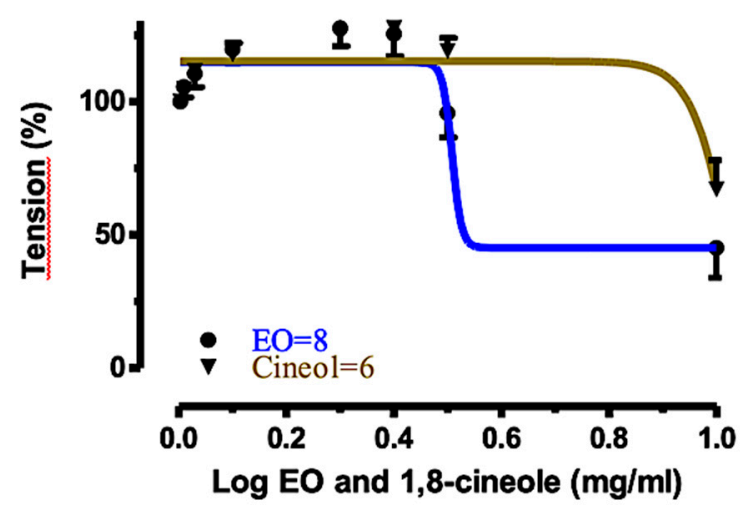

Figure 3. Concentration-response curves for the relaxant effects of 1,8-cineole (1) and $\mathrm{EO}_{\mathrm{S}}$ on rat tracheal rings, precontracted with ACh $(10 \mu \mathrm{M})$.

\subsection{Relaxation Mechanism}

Aimed at clarifying possible molecular mechanisms involved in the relaxation induced by $\mathrm{EO}_{\mathrm{S}}$ in tracheal rings, we explored the effects of $\mathrm{EO}_{\mathrm{S}}$ on the roles of the $\mathrm{K}_{\mathrm{Ca}}$ and $\mathrm{Ca}^{2+}$ channels, and on NO release. Actually, the crucial roles of $\mathrm{K}_{\mathrm{Ca}}$ and L-type $\mathrm{Ca}^{2+}$ channels, as well as NO release in airway smooth muscle contraction are well known [17,23,25-29,33-35], and they are important therapeutic targets.

The concentration-response curve for the effect exerted by $\mathrm{EO}_{S}$ against tracheal rings precontracted with ACh $(10 \mu \mathrm{M})$ and preincubated with the calcium-activated $\mathrm{K}^{+}\left(\mathrm{K}_{\mathrm{Ca}}\right)$ channel blocker tetraethyl ammonium chloride (TEA), is shown in Figure 4, in comparison with the curve of the control. The two curves were almost superimposed, indicating that the inhibition of the $\mathrm{K}_{\mathrm{Ca}}$ channel was not a significant signaling pathway.

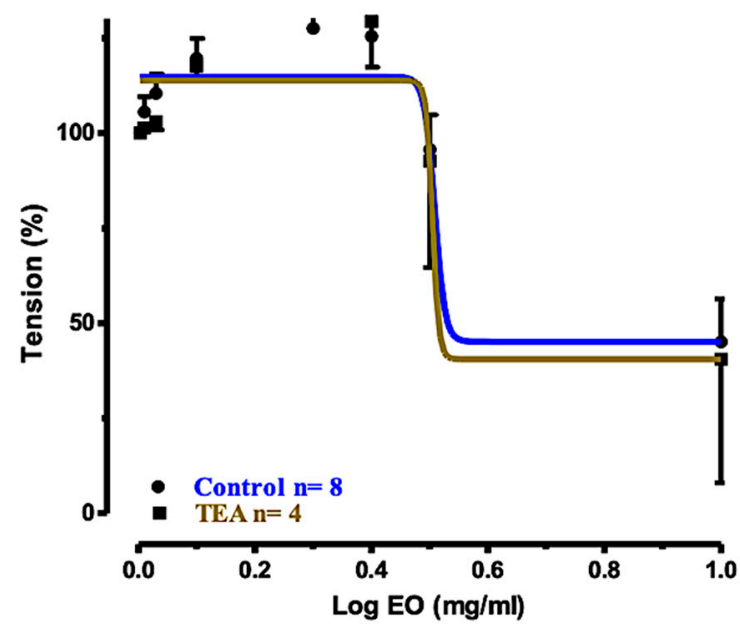

Figure 4. Concentration-response curves for the relaxant effects of $\mathrm{EO}_{\mathrm{S}}$ on rat tracheal rings precontracted with ACh $(10 \mu \mathrm{M})$ : control and preincubated with TEA $(1 \mathrm{mM})$.

In another experiment, we measured the relaxation induced by $\mathrm{EO}_{\mathrm{S}}$ in tracheal rings precontracted with $\mathrm{ACh}(10 \mu \mathrm{M})$ and preincubated with the L-type $\mathrm{Ca}^{2+}$ channel blocker nifedipine $(30 \mu \mathrm{M})$. The corresponding concentration-response curve with respect to the control is shown in Figure 5. In tracheal smooth muscle, blockade of voltage dependent $\mathrm{Ca}^{2+}$ channels (VDCs) by nifedipine at the extracellular surface of the membrane may attenuate bronchoconstriction [34]. Spasm evoked by ACh and the maintenance of spontaneous tone largely depend on mechanisms for increasing the cytoplasmic concentration of free $\mathrm{Ca}^{2+}$ which are resistant to nifedipine [35]. In the event, the relaxation effect induced by $\mathrm{EO}_{\mathrm{S}}$ was significantly reduced, suggesting that the presence of active constituents in 
the $\mathrm{EO}_{\mathrm{S}}$ can cause tracheal relaxation via the inhibition of $\mathrm{Ca}^{2+}$ influx through the plasma membrane in tracheal smooth muscle.

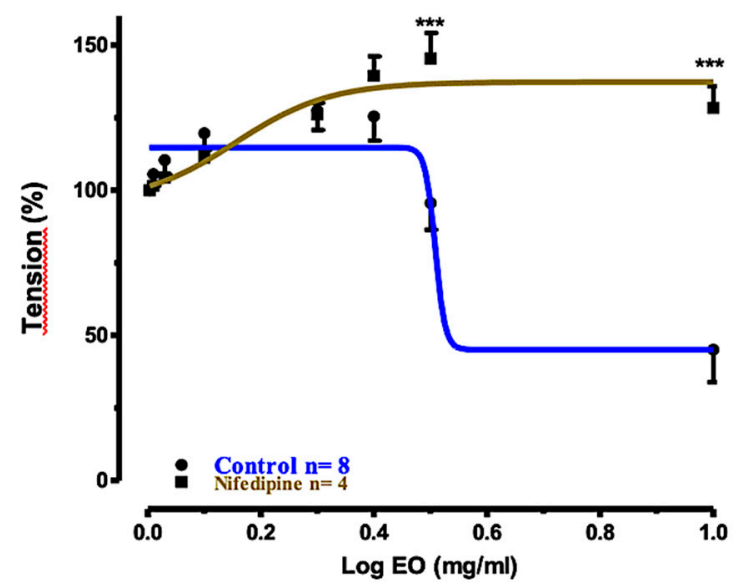

Figure 5. Concentration-response curves for the relaxant effects of $\mathrm{EO}_{\mathrm{S}}$ on rat tracheal rings precontracted with ACh $(10 \mu \mathrm{M})$ : control and preincubated with nifedipine $(30 \mu \mathrm{M}) .{ }^{* *} p<0.001$.

In the last experiment, the relaxant effect of $\mathrm{EO}_{\mathrm{S}}$ in tracheal rings precontracted with $\mathrm{ACh}$ and preincubated with NG-nitro-L-arginine methyl ester (L-NAME) was measured. L-NAME is a very well-known endothelial NO synthase inhibitor. The concentration-response curve of EOS, compared to the control, is shown in Figure 6. The graphic shows that the relaxation was attenuated to some extent; however, $\mathrm{EO}_{\mathrm{S}}$ was still quite effective (45.41\% relaxation).

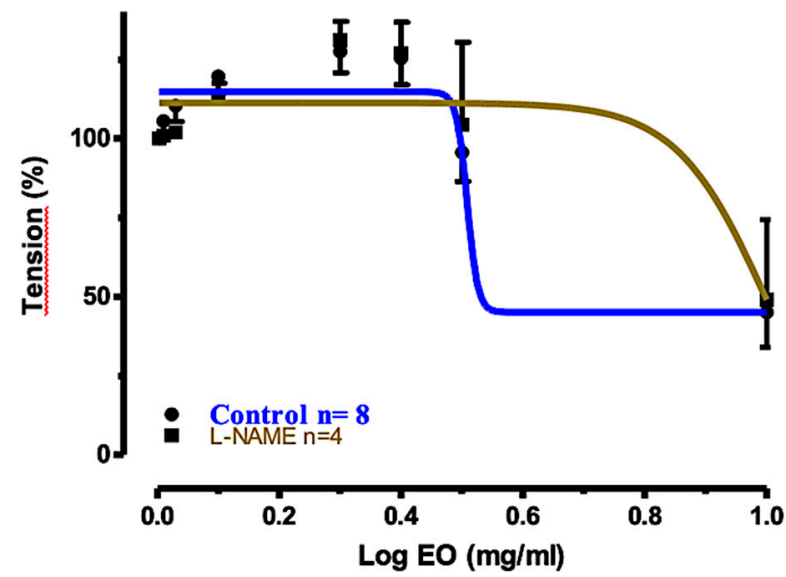

Figure 6. Concentration-response curves for the relaxant effects of $\mathrm{EO}_{\mathrm{S}}$ on rat tracheal rings precontracted with ACh $(10 \mu \mathrm{M})$ : control and preincubated with L-NAME $(0.3 \mathrm{mM})$.

Table 3 shows the $\log \mathrm{EC}_{50}$, the $95 \% \mathrm{CI}$ values, and the percentages of tracheal ring relaxation calculated from the concentration-response curves (Figures 4-6) determined for $\mathrm{EO}_{\mathrm{S}}$ in the three tests, compared to the control. In conclusion, these experiments clearly indicated that the pretreatment of tracheal rings with TEA or with L-NAME was unable to alter significantly the dose-dependent relaxant effects exerted by $\mathrm{EO}_{\mathrm{S}}$. Therefore, the $\mathrm{K}_{\mathrm{Ca}}$ channel and $\mathrm{NO}$ release and activation of the NO-cGMP pathway were not significantly involved in the relaxation mechanism. Instead, the inhibitory effect of $\mathrm{EO}_{\mathrm{S}}$ in tracheal rings preincubated with nifedipine blocked the concentration-response relaxation, indicating that L-type $\mathrm{Ca}^{2+}$ channels were significantly $(\mathrm{P}<0.001)$ involved in the relaxation mechanism. 
Table 3. Relaxant effects of volatile fractions $\left(\mathrm{EO}_{\mathrm{S}}\right)$ in tracheal rings preincubated with $\mathrm{K}^{+}$and $\mathrm{Ca}^{2+}$ channel blockers, and with NG-nitro-L-arginine methyl ester (L-NAME), respectively.

\begin{tabular}{|c|c|c|c|c|}
\hline $\begin{array}{l}\text { Treatment of } \\
\text { Tracheal Rings }\end{array}$ & Control & $\begin{array}{l}\text { Preincubated with } \\
\text { TEA (1 mM) }\end{array}$ & $\begin{array}{l}\text { Preincubated with } \\
\text { Nifedizpine }(30 \mu \mathrm{M})\end{array}$ & $\begin{array}{l}\text { Preincubated with } \\
\text { L-NAME }(0.3 \mathrm{mM})\end{array}$ \\
\hline $\log \mathrm{EC}_{50}$ & 0.508 & 0.505 & 0.156 & 1.014 \\
\hline $95 \%$ CI for $\log \mathrm{EC}_{50}$ & (Very wide) & (Very wide) & -0.0466 to 0.3577 & (Very wide) \\
\hline Relaxation $(\%) \pm$ SEM & $79.44 \% \pm 9.101$ & $73.68 \% \pm 10.39$ & $-26.42 \% \pm 10.79$ & $45.41 \% \pm 10.31$ \\
\hline
\end{tabular}

\section{Materials and Methods}

\subsection{Plant Material}

Fresh leaves of E. camaldulensis Dehnh. were collected in January 2010 near the Duhok Damp, in the Iraqi Kurdistan region, and were identified by Prof. Dr. Saleem Shahbaz, of the Herbarium of the Department of Biology, Faculty of Science, University of Zakho. The plant name has been checked with http://www.theplantlist.org on 08.24.2019. The plant is neither endangered nor protected in Kurdistan, and no specific permission was required for the collection. A voucher has been deposited at the Herbarium with the accession number AC031. The leaves were rinsed with tap water, air-dried for about twenty days at $20-25^{\circ} \mathrm{C}$ in the shade, and ground in an electrical mill (IKA-WERKE, Staufen im Breisgau, Germany) to a fine powder just prior to extraction.

\subsection{Chemicals}

Heparin and racemic ketamine were purchased from Hikma Pharmaceuticals (Amman, Jordan); xylazine, phenylephrine hydrochloride, TEA, L-NAME from Sigma-Aldrich (St. Louis, MO, USA); nifedipine from Medochemie (Limassol, Cyprus); ACh from Acros Organics-Fisher Scientific (Madison, WI, USA).

\subsection{Isolation of Volatile Fractions EO}

Five volatile fractions EO were obtained as dense oils by two different procedures: (i) Hydrodistillation provided fractions $\mathrm{EO}_{\mathrm{S}}, \mathrm{EO}_{\mathrm{W}}, \mathrm{EO}_{\mathrm{A}}$, and $\mathrm{EOAr}$ (see Section 3.3); (ii) $\mathrm{CO}_{2}$ extraction at atmospheric pressure afforded fraction $\mathrm{EO}_{\mathrm{D}}$ (see Section 3.4). All samples were dissolved in dichloromethane and analyzed by GC-FID and GC-MS.

\subsection{Hydrodistillation}

Powdered air-dried leaves of E. camaldulensis were hydrodistilled in a standard Clevenger-type apparatus, by two different procedures, A and B. In procedure A, named hydrodistillation with circulating-water, condensed water was circulating, while water was not circulating in procedure B. In mode A, leaves (3 lots of $250 \mathrm{~g}$ each) were hydrodistilled and volatiles were collected in a cylindrical glass condenser, where an oily layer (labeled $\mathrm{EO}_{\mathrm{S}}$ ) accumulated at the top of an aqueous phase. The latter could return by gravity to the distillation pot connected to the tip of the collector tube through a plastic tube. Water condensation and dipping in the pot were synchronized, so as to leave about $10 \mathrm{~mL}$ of an aqueous layer in the condenser. After $2.5 \mathrm{~h}$ of distillation no more oil apparently accumulated at the top of the aqueous phase. $\mathrm{EO}_{\mathrm{S}}$ was carefully separated from the aqueous layer by a micropipette, dried over anhydrous $\mathrm{Na}_{2} \mathrm{SO}_{4}$, filtered using Whatman filter paper (No.1), and stored at $-20{ }^{\circ} \mathrm{C}$ in a sealed vial until analysis. The average yield over 3 distillations was $0.98 \pm 0.02 \%(w / w)$. This oil was considered as the reference essential oil of E. camaldulensis leaves. In mode B. named hydrodistillation with non-circulating-water, the leaves were hydrodistilled (3 repetitions from lots of $250 \mathrm{~g}$ each) while the total condensed aqueous phase remained in the collector tube during the entire distillation time $(2.5 \mathrm{~h})$. After $1 \mathrm{~h}$ from the end of distillation, two phases clearly separated in the condenser. The accumulated oily layer, labeled $\mathrm{EO}_{\mathrm{W}}$ [average yield $0.88 \pm 0.02 \%(w / w)$ ] was carefully removed from the top of the hydrosol and treated as described for $\mathrm{EO}_{\mathrm{S}}$. The condensed aromatic aqueous layer (Aq, 
about $750 \mathrm{~mL}$ ) from each hydrodistillation was subjected to multiple solid phase extraction (SPE). To this purpose, a home-made cartridge was prepared by packing $10 \mathrm{~g}$ of Lichroprep RP-18 powder inside a glass syringe-like tube; subsequently, the reversed phase was washed with $\mathrm{MeOH}(50 \mathrm{~mL})$, followed by deionized water $(50 \mathrm{~mL})$, and then dried under vacuum. Each fraction Aq was divided in $80 \mathrm{~mL}$ portions, which were individually subjected to SPE. Each portion was added to the top of the column, which was then drained out under vacuum, collecting the liquid (F). The column was then washed with $\mathrm{MeOH}(50 \mathrm{~mL})$, and the eluate $(\mathrm{E})$ was collected. The experiment was then repeated with a new portion of Aq, following an identical procedure. Subsequently, all $\mathrm{F}$ and $\mathrm{E}$ fractions were separately collected together and carefully evaporated under reduced pressure $(200 \mathrm{mmHg})$ to give two oily residues, $\mathrm{EO}_{\mathrm{Ar}}$ (average yield $0.05 \pm 0.015 \%$ ) and $\mathrm{EO}_{\mathrm{A}}$ (average yield $0.28 \pm 0.01 \%$ ), respectively, which were stored under $\mathrm{N}_{2}$ in sealed vials at $-20^{\circ} \mathrm{C}$ until analysis.

\section{5. $\mathrm{CO}_{2}$ Extraction}

A sample of powdered dried leaves $(250 \mathrm{~g})$ was submitted to $\mathrm{CO}_{2}$ extraction at atmospheric pressure for $2 \mathrm{~h}$, in a home-made glass equipment, according to the method described by Honkanen and Karvonen [36]. An oily residue $\left(\mathrm{EO}_{\mathrm{D}}\right.$, yield $\left.=0.004 \%\right)$ was obtained which was stored under $\mathrm{N}_{2}$ in a sealed vial at $-20^{\circ} \mathrm{C}$ until analysis. Given the low yield, $\mathrm{CO}_{2}$ extraction was not repeated.

\subsection{GC-FID Analysis}

GC-FID analyses of the different volatile fractions (EO) were performed on a Perkin Elmer Auto system gas chromatographer equipped with a HP5 capillary column $(25 \mathrm{~m} \times 0.32 \mathrm{~mm}$ i.d.; $0.52 \mu \mathrm{m}$ film thickness). Nitrogen was used as the carrier gas at a flow rate of $1.5 \mathrm{~mL} / \mathrm{min}$. The injector operated in split mode (split ratio $25: 1$ ) and was heated at $220^{\circ} \mathrm{C}$. The GC oven temperature was hold at 60 ${ }^{\circ} \mathrm{C}$ for $1 \mathrm{~min}$, then increased by a gradient of $3{ }^{\circ} \mathrm{C} / \mathrm{min}$ until $100{ }^{\circ} \mathrm{C}$, hold at $100{ }^{\circ} \mathrm{C}$ for $30 \mathrm{~min}$, then increased to $250^{\circ} \mathrm{C}$ by a gradient of $10{ }^{\circ} \mathrm{C} / \mathrm{min}$, finally hold at $250^{\circ} \mathrm{C}$ for $5 \mathrm{~min}$. Each analysis lasted $64.3 \mathrm{~min}$. One microliter of each oil $\left(5 \%\right.$ in $\left.\mathrm{CH}_{2} \mathrm{Cl}_{2}\right)$ was injected in each analysis. Percentages (\%) of compounds $>0.01$ occurring in each EO (Table 1) were calculated from the corresponding GC peak areas with respect to the total peak area in the GC-FID chromatogram without applying any correction factor. Three GC-FID analyses were performed for $\mathrm{EO}_{S}$ and $\mathrm{EO}_{\mathrm{W}}$, while $\mathrm{EO}_{\mathrm{A}}, \mathrm{EO}_{\mathrm{Ar}}$, and $\mathrm{EO}_{\mathrm{D}}$ were analysed only once.

\subsection{GC-MS Analysis}

GC-MS analyses of the different volatile fractions (EO) were performed using an Agilent Bench Top GC-MS equipment, comprising a 6890N network gas-chromatographic system combined with a 5973 Network Mass Selective Detector (Agilent Technologies, Wilmington, DE, USA), and equipped with a DB-5 glass capillary column $(30 \mathrm{~m} \times 0.25 \mathrm{~mm}$ i.d.; $0.25 \mu \mathrm{m}$ film thickness). Helium was used as the carrier gas at a flow rate of $1 \mathrm{~mL} / \mathrm{min}$. Temperature of the injector: $220^{\circ} \mathrm{C}$; oven temperature program: isotherm at $60^{\circ} \mathrm{C}$ for $1 \mathrm{~min}$, then increased $\left(3^{\circ} \mathrm{C} / \mathrm{min}\right)$ to $270{ }^{\circ} \mathrm{C}$, followed by an isotherm at $270{ }^{\circ} \mathrm{C}$ for $5 \mathrm{~min}$. Sample split ratio: 1:20; $1 \mu \mathrm{L}$ of each oil $\left(5 \%\right.$ in $\left.\mathrm{CH}_{2} \mathrm{Cl}_{2}\right)$ was injected in each analysis. Mass spectra were acquired at $70 \mathrm{eV}$ within a mass range of 41-350 Daltons (Da) with a scan time of 0.73 scans s ${ }^{-1}$; ion source temperature: $230^{\circ} \mathrm{C}$. Compound identification was at first based on their linear retention indices (LRIs). They were calculated according to Van Den Dool and Kratz [20], with reference to a homologous series of $n$-alkanes $\mathrm{C}_{6}-\mathrm{C}_{20}$ (TPH-6RPM of CHEM SERVICE), which were injected immediately after each oil analysis under the same gas-chromatographic conditions. Calculated LRIs were compared with the retention indices of authentic samples or literature data $[18,19]$. Comparison of the retention indices was considered reasonable in a range of \pm 20 units. The identity of each EO constituents was confirmed by comparing the mass spectral fragmentation patterns with those reported in the literature $[18,19,21]$ and, whenever possible, with the GC-MS data of pure standard compounds. 


\subsection{Physiological Activities of Volatile Fractions}

Experiments on rats were performed according to the Iraqi and institutional rules considering animal experiments, and in accordance with the internationally accepted principles for laboratory animal use and care as found in the European Community guidelines (EEC Directive of 1986; $86 / 609 / \mathrm{EEC})$. Stock solutions $(0.05 \% \mathrm{~g} / \mathrm{L})$ of tested volatile fractions and 1,8-cineole were prepared by dissolving the desired amount in DMSO in which samples are completely soluble and which helped dissolution in water. They were kept refrigerated until analysis. Desired serial dilutions were then prepared by diluting stock solutions with aqueous $\mathrm{NaCl}(0.09 \% \mathrm{~g} / \mathrm{L})$ and warmed to $37{ }^{\circ} \mathrm{C}$ prior to use.

\subsection{Measurement of Isometric Force with Isolated Thoracic Aortic Rings}

Adult male albino rats, weighting 200-300 g each, were used for all experiments. They were kept in plastic cages at $24^{\circ} \mathrm{C}$ and were exposed to a photoperiod cycle of $12 \mathrm{~h}$ light followed by $12 \mathrm{~h}$ darkness. Rats were fed standard diet and tap water. Access to water was free, while food was removed $24 \mathrm{~h}$ prior to experiments. Rats were injected intraperitoneally with heparin (1500 units/Kg body weight), then left for $30 \mathrm{~min}$ to avoid blood clotting and possible damage of the aorta endothelium, and finally anaesthetized with racemic ketamine $(40 \mathrm{mg} / \mathrm{kg})$ and xylazine $(10 \mathrm{mg} / \mathrm{kg})$ intraperitoneally. Chest cavity was opened, and excess tissues and fat were removed. Aorta was isolated and transferred to a beaker containing a Krebs solution aerated with $95 \% \mathrm{O}_{2}$ and $5 \% \mathrm{CO}_{2}$, that was placed in a water-bath at $37^{\circ} \mathrm{C}$. Subsequently, the aorta was segmented into rings $3-5 \mathrm{~mm}$ long. Isolated thoracic aortic rings were used in preparations with intact endothelium. Aortic rings were mounted between two stainless steel hooks, connected by a thread to a force transducer coupled to a transbridge amplifier and a Power Lab Data Acquisition system (model ML 870, Power Lab, AD Instrument, Sydney, Australia), which was connected to a computer running chart software (Version 7). The isometric force produced was monitored and recorded. Experiments were performed in $10 \mathrm{~mL}$ organ baths filled with a physiological Krebs solution ( $\mathrm{pH}=7.4$ ) maintained at $37^{\circ} \mathrm{C}$ by means of a thermoregulating system with water continuously circulating throughout a double-walled water-jacketed system, and continuously gassed with $95 \% \mathrm{O}_{2}$ and $5 \% \mathrm{CO}_{2}$. Tension was set at $2 \mathrm{~g}$ for $60 \mathrm{~min}$, and the buffer solution was changed every 15 min until the resting tone became constant. After these numerous washings most xylazine was considered to have been removed from the organ so that its effect on the tissue was negligible. Sample concentration-response curves were then determined, with phenilephrine $(1 \mu \mathrm{M})$ used as the aorta ring-contraction agonist.

\subsection{Measurement of Isometric Force with Isolated Tracheal Rings}

Trachea was removed from anaesthetized rats, cleaned, and segmented into 3-5 mm long rings (each containing 3-4 cartilaginous rings). Measurements of the isometric force with isolated tracheal rings were then performed according to international standard procedures for in vitro study using organ bath. Rings were suspended in $10 \mathrm{~mL}$ organ baths filled with physiological Krebs solution $(\mathrm{pH}=$ 7.4), maintained at $37^{\circ} \mathrm{C}$ by a thermoregulating system with continuous water circulating throughout a double walled water jacket system, and aerated with $95 \% \mathrm{O}_{2}$ and $5 \% \mathrm{CO}_{2}$. Tracheal rings were maintained under an isometric tension of $2 \mathrm{~g}$ and allowed to stabilize for $60 \mathrm{~min}$, while changing the Krebs solution every $15 \mathrm{~min}$. After these numerous washings most xylazine was considered to have been removed from trachea so that its effect on the tissue was negligible. Concentration-response curves (Figures 3-6 and Table 3) were then determined adding increasing amounts of $\mathrm{EO}_{\mathrm{S}}$ and 1,8-cineole, in separate experiments. ACh $(10 \mu \mathrm{M})$ was used as the tracheal ring-contraction agonist. In subsequent experiments, increasing amounts of $\mathrm{EO}_{\mathrm{S}}$ were added to tracheal rings preincubated with the $\mathrm{K}^{+}$channel blocker TEA $(1 \mathrm{mM})$ for $20 \mathrm{~min}$ and then precontracted with $\mathrm{ACh}(10 \mu \mathrm{M})$. Analogous experiments were performed with tracheal rings preincubated with nifedipine $(30 \mu \mathrm{M})$ for 10 min prior to precontraction with ACh $(10 \mu \mathrm{M})$. Finally, tracheal rings were preincubated with L-NAME $(0.3 \mathrm{mM})$ for $10 \mathrm{~min}$. prior to precontraction with $\mathrm{ACh}(10 \mu \mathrm{M})$; then, increasing amounts of EOS were added. 


\subsection{Statistical Analysis}

The vasorelaxation response, calculated as a percentage of contraction produced by PE or ACh, was expressed as the mean \pm standard error of the mean (SEM). The base line tension was expressed as a measure of $100 \%$ relaxation, and the tension induced by agonist was taken as a measure of $0 \%$ relaxation. All data analyses were fitted with a Hill equation, that the median effective concentration (Log of $\mathrm{IC}_{50}$ ) value was given as geometric mean with $95 \%$ confidence intervals $(95 \% \mathrm{CI})$, using the statistics program GraphPad Prism ${ }^{\text {TM }}$ software, version 6 (GraphPad Software, Inc., San Diego, CA, USA). Two-way analysis of variance (ANOVA) was performed, supported with Bonferroni test when carrying out pairwise comparison between the same doses of different groups using GraphPad program. $p$-Values less than $0.05(p<0.05)$ were considered significant. Symbols ${ }^{*}$ mean $p<0.05,{ }^{* *} p<$ 0.01 and $^{* * *} p<0.001$ for all graphs.

\section{Conclusions}

In this study the chemical profiles of the volatile fractions isolated from air-dried leaves of $E$. camaldulensis Dehnh. collected in Iraqi Kurdistan, were investigated for the first time. Essential oils $\mathrm{EO}_{\mathrm{S}}$ and $\mathrm{EO}_{\mathrm{W}}$, respectively, were obtained by hydrodistillation with circulating water and with non-circulating-water, respectively. They were compared with an oil $\left(\mathrm{EO}_{\mathrm{D}}\right)$ obtained by $\mathrm{CO}_{2}$ extraction. The first two methods were much more efficient in terms of oil yield and number of oil components. A total of 31 and 42 components have been identified and quantified in $\mathrm{EO}_{\mathrm{S}}$ and $\mathrm{EO}_{\mathrm{W}}$, respectively, by GC-FID and GC-MS, and comparison with literature databases. They accounted for more than $98 \%$ of the contents of the two oils. In both $\mathrm{EO}_{\mathrm{S}}$ and $\mathrm{EO}_{\mathrm{W}}$, monoterpenoids prevailed over sesquiterpenoids, and oxygenated monoterpenes were more abundant than monoterpene hydrocarbons. The major components of $\mathrm{EO}_{\mathrm{S}}$ and $\mathrm{EO}_{\mathrm{W}}$, accounting for more than $80 \%$, were 1,8-cineole (1, about $\left.60 \%\right)$, followed by $p$-cymene (2), $\alpha$-pinene (3), terpinen-4-ol (4), aromadendrene (5), and $\alpha$-terpineol (6).

In conclusion, the volatile fractions isolated from E. camaldulensis leaves collected in Kurdistan contained important and widely used flavor and fragrance ingredients. Most constituents, mainly 1,8-cineole (1) and other oxygenated monoterpenoids, are biologically active, exhibiting well-known antibacterial, bronchodilatory, anti-inflammatory, and analgesic effects $[2,5,26-33,37,38]$. In this regard, we have shown that the relaxant activity of the volatile fractions does not depend only on the most abundant constituent, 1,8-cineole (1), but it is likely due to the synergistic effects of different monoterpenoids. An important pathway for the relaxation effects exerted by E. camaldulensis volatile fractions involves the inhibition of $\mathrm{Ca}^{2+}$ influx through the plasma membrane in tracheal smooth muscle.

We are all well-aware that the chemical composition of vapors inhaled from a leaf hot tea can be different from that of a volatile fraction isolated by hydrodistillation, such as $\mathrm{EO}_{\mathrm{S}}$, and should be analyzed by techniques such as solid phase microextraction (SPME)-GC-MS. However, it appears plausible that most of the bioactive components of the EOs also occur in the vapors, although the relative percentages can be different. Thus, based on our findings, we believe that inhalation of vapors from a hot aqueous infusion of E. camaldulensis leaves for treating the symptoms of respiratory tract diseases, is sustained by scientific evidence.

Author Contributions: Conceptualization, Methodology, and Supervision, O.A.M.A.-H. and G.V.; Investigation, D.A.K. and G.G.; Resources, O.A.M.A.-H. and G.V.; Data Curation, D.A.K. and G.G.; Writing-Original Draft Preparation, D.A.K.; Writing-Review and Editing, G.V. This manuscript, or parts thereof, has not been submitted for possible publication to another journal nor the work has previously been published elsewhere. All authors have read and agreed to the published version of the manuscript.

Funding: This research did not receive any specific grant from funding agencies in the public, commercial, or not-for-profit sectors.

Acknowledgments: We are grateful to the Universidad Técnica Particular de Loja (UTPL) for supporting open access publication.

Conflicts of Interest: The authors declare no conflict of interest. 


\section{References}

1. Shahbaz, S.I. Trees and Shrubs, 1st ed.; University of Duhok: Kurdistan, Iraq, 2010.

2. Akin, M.; Aktumsek, A.; Nostro, A. Antibacterial activity and composition of the essential oils of Eucalyptus camaldulensis Dehnh. and Myrtus communis L. growing in Northern Cyprus. Afr. J. Biotechnol. 2010, 9, 531-535.

3. Abd El-Mageed, A.A.; Osman, A.K.; Tawfik, A.Q.; Mohammed, H.A. Chemical composition of the essential oils of four Eucalyptus Species (Myrtaceae) from Egypt. Res. J. Phytochem. 2011, 5, 115-122.

4. Şahin-Bölükbaşı, S.; Candan, F. Chemical composition and in vitro antioxidant and antidiabetic activities of Eucalyptus camaldulensis Dehnh. essential oil. J. Iran. Chem. Soc. 2010, 7, 216-226. [CrossRef]

5. Lima, L.M.; Babakhani, B.; Boldaji, S.A.H.; Asadi, M.; Boldaji, R.M. Essential oils composition and antibacterial activities of Eucalyptus camaldulensis Dehn. Int. J. Med. Arom. Plants 2013, 3, 214-219.

6. Sefidkon, F.; Bahmanzadegan, A.; Assareh, M.H.; Abravesh, Z. Seasonal variation in volatile oil of Eucalyptus species in Iran. J. Herbs Spices Med. Plants (IJHSMP) 2009, 15, 106-120. [CrossRef]

7. Gakuubi, M.M. Steam distillation extraction and chemical composition of essential oils of Toddalia asiatica L. and Eucalyptus camaldulensis Dehnh. J. Pharmacogn. Phytochem. 2016, 5, 99-104.

8. Grbović, S.; Orčić, D.; Couladis, M.; Jovin, E.; Bugarin, D.; Balog, K.; Mimica-Dukić, N. Variation of essential oil composition of Eucalyptus camaldulensis (Myrtaceae) from the Montengero coastline. Acta Period. Technol. 2010, 41, 151-158. [CrossRef]

9. Knezevic, P.; Aleksic, V.; Simin, N.; Svircev, E.; Petrovic, A.; Mimica-Dukic, N. Antimicrobial activity of Eucalyptus camaldulensis essential oils and their interactions with conventional antimicrobial agents against multi-drug resistant Acinetobacter baumannii. J. Ethnopharmacol. 2016, 178, 125-136. [CrossRef]

10. Ashraf, M.; Ali, Q.; Anwar, F.; Hussain, A.I. Composition of leaf essential oil of Eucalyptus camaldulensis. Asian J. Chem. 2010, 22, 1779-1786.

11. El-Ghorab, A.H.; El-Massry, K.F.; Anjum, F.M.; Shahwarb, M.K.; Shibamoto, T. The chemical composition and antioxidant activity of essential oil of Pakistani Eucalyptus camaldulensis leaves. J. Essent Oil-Bear. Plants 2009, 12, 262-272. [CrossRef]

12. Ndiaye, E.H.B.; Diop, M.B.; Gueye, M.T.; Ndiaye, I.; Diop, S.M.; Fauconnier, M.-L.; Lognay, G. Characterization of essential oils and hydrosols from Senegalese Eucalyptus camaldulensis Dehnh. J. Essent. Oil Res. 2018, 30, 131-141. [CrossRef]

13. Akin-Osanaiye, B.C.; Agbaji, A.S.; Dakare, M.A. Antimicrobial Activity of Oils and Extracts of Cymbopogon citratus (Lemon Grass), Eucalyptus citriodora and Eucalyptus camaldulensis. J. Med. Sc. 2007, 4, 694-697. [CrossRef]

14. Aleksic Sabo, V.; Knezevic, P. Antimicrobial activity of Eucalyptus camaldulensis Dehn. plant extracts and essential oils: A review. Ind. Crop Prod. 2019, 132, 413-429. [CrossRef]

15. Chevallier, A. The Encyclopedia of Medicinal Plants: An Excellent Guide to Over 500 of the More Well-Known Medicinal Herbs from around the World; Dorling Kindersley: London, UK, 1966.

16. Begum, S.; Farhat, F.; Sultana, I.; Siddiqui, B.S.; Shaheen, F.; Gilani, A.H. Spasmolytic constituents from Eucalyptus camaldulensis var. obtusa leaves. J. Nat. Prod. 2000, 63, 1265-1268. [CrossRef]

17. Al-Habib, O.A.M.; Kheder, A.D.; Vidari, G.; Gilardoni, G. Relaxant effects of essential oils of Eucaluptus camaldulensis on aortic rings in male albino rats. Sci. J. Univ. Zakho 2013, 1, 139-146.

18. Adams, R.P. Identification of Essential Oil Components by Gas Chromatography/Mass Spectrometry, 4th ed.; Allured Publishing Corporation: Carol Stream, IL, USA, 2007.

19. NIST Chemistry WebBook, SRD 69. 2018. Available online: https://doi.org/10.18434/T4D303 (accessed on 30 December 2019).

20. Van Den Dool, H.; Kratz, P.D. A generalization of the retention index system including linear temperature programmed gas-liquid partition chromatography. J Chromatogr. 1963, 11, 463-471. [CrossRef]

21. Wiley Registry, 11th ed.; NIST 2017 Mass Spectral Library; Wiley: New York, NY, USA; NIST: Gaithersburg, MD, USA, 2017; ISBN 978-1-119-41223-6.

22. Moudachirou, M.; Gbénou, J.D.; Chalchat, J.C.; Chabard, J.L.; Lartigue, C. Chemical composition of essential oils of Eucalyptus from Bénin: Eucalyptus citriodora and E. camaldulensis. Influence of location, harvest time, storage of plants and time of steam distillation. J. Essent. Oil Res. 1999, 11, 109-118. [CrossRef] 
23. Ribeiro, T.P.; Porto, D.L.; Menezes, C.P.; Antunes, A.A.; Silva, D.F.; De Sousa, D.P.; Nakao, L.S.; Braga, V.A.; Medeiros, I.A. Unravelling the cardiovascular effects induced by alpha-terpineol: A role for the nitric oxide-cGMP pathway. Clin. Exp. Pharmacol. Physiol. 2010, 37, 811-816. [CrossRef]

24. Perez-Hernandez, N.; Ponce-Monter, H.; Ortiza, M.I.; Carino-Cortes, R.; Joseph-Nathan, P. Structure-activity relationships of aromadendranes in uterus-relaxant activity. Z. Naturforsch. 2009, 64C, 840-846. [CrossRef]

25. Peixoto-Neves, D.; Silva-Alves, K.S.; Gomes, M.D.M.; Lima, F.C.; Lahlou, S.; Magalhães, P.J.C.; Ceccatto, V.M.; Coelho-de-Souza, A.N.; Leal-Cardoso, J.H. Vasorelaxant effects of the monoterpenic phenol isomers, carvacrol and thymol, on rat isolated aorta. Fund. Clin. Pharmacol. 2010, 24, 341350. [CrossRef]

26. Coelho-de-Souza, L.N.; Leal-Cardoso, J.H.; de Abreu Matos, F.J.; Lahlou, S.; Magalhães, P.J. Relaxant effects of the essential oil of Eucalyptus tereticornis and its main constituent 1,8-cineole on guinea-pig tracheal smooth muscle. Planta Med. 2005, 71, 1173-1175. [CrossRef] [PubMed]

27. Nascimento, N.R.F.; de Refosco, R.M.C.; Vasconcelos, E.C.F.; Kerntopf, M.R.; Santos, C.F.; Batista, F.J.A.; De Sousa, C.M.; Fonteles, M.C. 1,8-Cineole induces relaxation in rat and guinea-pig airway smooth muscle. J. Pharm. Pharmacol. 2009, 61,361-366. [CrossRef] [PubMed]

28. Pinto, N.V.; Assreuy, A.M.S.; Coelho-de-Souza, A.N.; Ceccatto, V.M.; Magalhães, P.J.C.; Lahlou, S.; Leal-Cardoso, J.H. Endothelium-dependent vasorelaxant effects of the essential oil from aerial parts of Alpinia zerumbet and its main constituent 1,8-cineole in rats. Phytomedicine 2009, 16, 1151-1155. [CrossRef] [PubMed]

29. Soares, M.C.M.S.; Damiani, C.E.N.; Moreira, C.M.; Stefanon, I.; Vassallo, D.V. Eucalyptol, an essential oil, reduces contractile activity in rat cardiac muscle. Braz. J. Med. Biol. Res. 2005, 38, 453-461. [CrossRef] [PubMed]

30. Juergens, U.R. Anti-inflammatory properties of the monoterpene 18-cineole: Current evidence for co-medication in inflammatory airway diseases. Drug Res. 2014, 64, 638-646.

31. Santos, F.A.; Rao, V.S. Antiinflammatory and antinociceptive effects of 1,8-cineole a terpenoid oxide present in many plant essential oils. Phytother Res. 2000, 14, 240-244. [CrossRef]

32. Hardel, D.K.; Sahoo, L. A review on phytochemical and pharmacological of Eucalyptus globulus: A multipurpose tree. Int. J. Res. Ayurveda Pharm. 2011, 2, 1527-1530.

33. Santos, M.R.V.; Moreira, F.V.; Fraga, B.I.S.P.O.; De Sousa, D.O.; Bonjardim, L.R.; Quintans-Junior, L.J. Cardiovascular effects of monoterpenes: A review. Rev. Bras. Pharmacogn. 2011, 21, 764-771. [CrossRef]

34. Hirota, K.; Hashiba, E.; Yoshioka, H.; Kabara, S.; Matsuki, A. Effects of three different L-type Ca ${ }^{2+}$ entry $^{-}$ blockers on airway constriction induced by muscarinic receptor stimulation. Br. J. Anaesth. 2003, 90, 671-675. [CrossRef]

35. Ahmed, F.; Foster, R.W.; Small, R.C. Some effects of nifedipine in guinea-pig isolated trachealis. Br. J. Pharmacol. 1988, 84, 861-869. [CrossRef]

36. Honkanen, E.; Karvonen, P. Isolation of volatile flavour compounds from fats and oils by vacuum carbon dioxide distillation. Acta Chem. Scand. 1966, 20, 2626-2627. [CrossRef] [PubMed]

37. Silva, J.; Abebe, W.; Sousa, S.M.; Duarte, V.G.; Machado, M.I.; Matos, F.J. Analgesic and anti-inflammatory effects of essential oils of Eucalyptus. J. Ethnopharmacol. 2003, 89, 277-283. [CrossRef] [PubMed]

38. Ghalem, B.R.; Mohamed, B. Antibacterial activity of essential oil of north west Algerian Eucalyptus camaldulensis against Escherichia coli and Staphylococcus aureus. J. Coast. Life Med. 2014, 2, 799-804. [CrossRef]

Sample Availability: Samples of the compounds are not available from the authors. 